\title{
THE DISPARITIES IN SECTION 3, HEARSAY- ADMISSIBILITY RULES AND THE NEGATIVE EFFECTS THE CONSENT CLAUSE IN SECTION 3(1)(A) HAS ON THE ACCUSED WHOSE REPRESENTATIVES AGREE TO THE ADMISSION OF HEARSAY EVIDENCE TO PROVE A CASE AGAINST THEIR CLIENTS*
}

\section{Introduction}

In order to safeguard invaluable evidence from being eroded (Schwikkard and Van der Merwe Principles of Evidence 3ed (2009) 27; and also refer to $S$ v Saeed [2012] JOL 29299 (FB) par 32) and contrary to the outcry against this move (the admissibility of hearsay evidence has for ever attracted controversy and endless appeals by the aggrieved convicts), our law of evidence anticipated the need for the admission of hearsay evidence which was previously inadmissible in terms of our common law. (The common law pertaining to hearsay evidence was the relevant English common law as at 30 May 1961. Under this law hearsay evidence was inadmissible except in cases where the common-law exceptions applied. Schwikkard and Van der Merwe Principles of Evidence 27.) To do this, the Law of Evidence Amendment Act (45 of 1988) became operative. Thus the intention of the legislation is that this Act operates to solve possible prejudices in relation to the loss of hearsay evidence which would otherwise be inadmissible. (See the rationale for the foundations and the need for admissibility of hearsay evidence in Paizes The Concept of Hearsay with Particular Emphasis on the Implied Hearsay Assertions (LLD thesis, Wits University, 1983). Chapter 5 in particular 200-226.) It is apparent from case law dealing with the admissibility of hearsay evidence that the interpretation of this Act in the context of the Constitutional right to fair trial divulges yet another purpose namely, to protect the accused from uncalled-for prejudices through the use of hearsay evidence in the conduct of criminal trials (see $S v$ Ngwani 1990 (1) SACR 449; $S v$ Dyimbane 1990 (2) SACR 502 (SE); S v Cekiso 1990 (4) SA 20 (E); S v Ndhovu 1993 (2) SACR 69 (A); S v Ramavhale 1996 (1) SACR 639 (A); S v Ndhlovu 2002 (2) SACR 325 (SCA); S v Molimi 2008 (2) SACR 76 (CC); and $S$ v Libazi 2010 (2) SACR 233 (SCA)).

The application of this law was subjected to its compatibility with the provisions of any other law applicable in South Africa. (This is provided in $\mathrm{S}$ 3(1) of Act 45 of 1988, hence in $S v$ Molimi supra par 34, the Constitutional

I wish to thank Prof Vinesh Basdeo and Dr Johnson Mathenjwa for their constructive comments on the draft of this article. 
Court held in accordance with these provisions that admissibility of hearsay evidence in terms of $\mathbf{s} 3$ of the Act could not apply contrary provisions of $s 219$ of the Criminal Procedure Act.) Although it was in the best intention of the legislature that this Act operated to solve possible prejudices in regard to the loss of hearsay evidence which would be otherwise admissible, its implementation has posed more problems than a solution. Mostly with respect to the recent practice in criminal courts, where hearsay evidence in the form of statements by witnesses, even though available, witnesses were not summoned to court to testify, accused persons are exposed to excessive prejudice. Coupled with this scenario is the situation where parties consent to hearsay evidence.

In terms of section 3, hearsay evidence is admissible under three conditions: first, through consent of parties to the lawsuit (s 3(1)(a) of Act 45 of 1988); secondly, where the witness on whose credibility the truth and the extent of reliability of the evidence depend would come before court and undergo the court's scrutiny (s 3(1)(b) of Act 45 of 1988) and thirdly, where the court has established that the interest of justice demands the admissibility of hearsay evidence (s 3(1)(c) of Act 45 of 1988). The application of these provisions is not cumulative, implying that each of them is independently applied. This results in the possibility of uneven processes by courts in testing the admissibility of hearsay evidence. In some cases the exception to the hearsay requirement attracts judicial scrutiny of such evidence for any potential prejudice, while in some cases it would not be the duty of the court to intervene regarding any harm hearsay evidence poses.

This article will examine the weaknesses that these disparities pose in finding justice through the use of hearsay evidence in terms of section 3 of Act 45 of 1988. I shall endeavour to show that in criminal cases, consent to hearsay evidence provided in section 3(1)(a) is even more detrimental to the administration of justice. This I shall endeavour to do through discussing the application of section $3(1)(b)$ to expose statutory protections in this section which are not present when section 3(1)(a) is used. Further, I shall explain how possible prejudice against accused persons is safeguarded by the provisions in section 3(1)(c) which safeguards are not applicable on the admissibility of hearsay evidence in terms of section 3(1)(a). It will be apparent in my analysis that seeking justice through the invocation of hearsay evidence is not such a perfect exercise even if section 3(1)(c) is invoked. (In a recently decided matter on the admissibility of hearsay evidence, Litako $v S$ (584/2013) [2014] ZASCA 54 (16 April 2014) par 31, the court exclaimed that past judgments and the number of cases filed before courts reflect that the law in this area is pregnant with complexities.)

\section{Background}

The implementation of Act 45 of 1988 is marred by more problems than solutions. These problems are causes of concern in our courts, to the extent that $S \vee$ Ramavhale (supra 37-38, per Schutz JA) considered that even though "hearsay evidence may be accepted subject to the broad, almost limitless criteria set out in s 3(1) ... the facts of life do not simply vanish at the flourish of the legislator's pen [because,] [h]earsay evidence was long recognised to tend to be unreliable, and continues to tend to be so" ( $R v$ 
Ramavhale supra 37-38, per Schutz JA). To prove that there are potential problems, "[t]he old works are replete with warning, based on the accumulation of the experience of centuries" ( $R v$ Ramavhale supra 37-38, per Schutz JA).

These words caution that, even though section 3 introduces "an almost limitless criterion" ( $R \vee$ Ramavhale supra 37-38, per Schutz JA) for the acceptance of hearsay evidence in the attempt to solve problems posed by the exclusion of hearsay, the challenges posed by admissibility of hearsay evidence could not be remedied by merely legislating on hearsay, but also by a cautious application of the legislation to attain its constitutional meaning. This then would mean that the importance of common-law cautions when dealing with admissibility of evidence cannot be overemphasized, and that the level of scrutiny that ensues upon admitting hearsay evidence has to even be more meticulous. Further, it would mean that if a scrupulous approach is adopted in dealing with the admissibility of hearsay evidence, the current flooding courts of appeal rolls, where persons convicted on the basis of inadmissible hearsay evidence ceaselessly challenge their convictions, would be reduced. (For a number of years, many cases of unsatisfied convicts have flooded the Supreme Court of Appeal, with some ending up at the Constitutional Court. The least of them includes the following, $S v$ Ramavhale supra; S v Ndhlovu 2002 (6) SA 305 (SCA); S v Ralukukwe 2006 (2) SACR 394 (SCA); Balkwell v S [2007] 3 All SA 465 (SCA); S v Mamushe [2007] 4 All SA 972 (SCA); S v Libazi supra; S v Molimi supra; S v Mangena 2012 (2) SACR 170; and Litako v S supra.) This would then indicate that the essential test for the satisfaction of the interests-of-justice requirement in admitting hearsay evidence is observed as early as at the trial stage to avoid unnecessary appeals.

Regarding section 3(1), there is a problem with the way courts apply the tests required in admitting hearsay evidence in criminal cases (per Ramapai J in $S v$ Saeed supra par 34). Not so long ago the High Court, sitting on a trial that considered admissibility of hearsay, remarked that "[i]n almost everyone of [these] criminal cases, judges of the high, supreme and constitutional court [are] at pains to sound words of caution about the erroneous admission of hearsay evidence that could be occasioned by any skewed application of the fundamental test" (per Ramapai $J$ in $S v$ Saeed supra par 34). These failures by courts imply a lack of a proactive approach where hearsay evidence has to be admitted in courts. This has clouded the recent practice of criminal trial courts. Most often than not, where hearsay evidence in the form of statements by witnesses, even though available, they are not present to testify, is admitted, accused persons are exposed to excessive prejudice contrary to constitutional safeguards. Indeed, the failures of engaging in proactive evaluations of factors emanating from well-established cautionary rules found in both common law and statutory law and ought to apply when courts are determining the admissibility of evidence, especially when dealing with hearsay evidence, seems a major problem in our criminal justice system. The impact of these failures is greater in some instances. 


\section{The application of section 3(1)(A) of Act 45 of 1988}

The worst of these instances arises in invoking the terms of section 3(1)(a). That is where defence consents to the admissibility of hearsay evidence introduced by the State to prove a case against the accused. The interpretation of section 3(1)(a) accommodates agreement in many forms, including direct or implied consent. Consent therefore exposes the defence to the fate of its own mistakes at the expense of the accused who stands at the mercy of the court because section 3(1)(a) has a potential to apply even in situations where by mistaken defence does not object to the admission of hearsay evidence being introduced by the State (Mohamed $v$ AttorneyGeneral of Natal 1996 (1) SACR $139(\mathrm{~N})$ ). This happens in differing ways, including situations where the defence does not appreciate the nature and extent of potential prejudice (Schwikkard and Van der Merwe Principles of Evidence 276; and Bellengère, Palmer, Theophilopoulos, Witcher, Roberts, Melville, Picarra, Illsley, Nkutha, Naudé, Van der Merwe and Reddy The Law of Evidence in South Africa Basic Principles (2013) 297). For example, where the defence does not object to the State while leading a witness on hearsay evidence, and the defence afterwards cross-examines the witness on the basis of such hearsay evidence (see $S v$ Congola 2002 (2) SACR (T) 386c-g; and $S v$ Aspeling 1998 (1) SACR 561(c) 567h-568b). Because it is not a requirement that hearsay evidence admitted in terms of section 3(1)(a) like in section 3(1)(b) and (c) instances be subjected to the test as to whether its admission is in the interest of justice, observes standards subject to the common-law cautionary rules, it is possible that in these situations the accused would be exposed to insurmountable prejudices.

Under these circumstances, the court would not find it necessary to establish whether it is in the interest of justice to admit hearsay evidence and to then delve into the duties established in section 3(1)(c), and consider whether the admitted hearsay evidence serves the best interest of justice. That is only done regarding admissibility of hearsay evidence in terms of section 3(1)(c).There would be no exercise of judicial discretion to decide every doubtful aspect of the hearsay evidence in terms of the cumulative factors in section 3(1)(c).

Where parties invoke section (3)(1)(a) they are deemed to have agreed unequivocally to the admissibility of the hearsay evidence. Thus the court would not find it necessary that witnesses testify so that the credibility of their evidence is examined through cross-examination. This would be different from the requirement in section 3(1)(b), enabling the court to engage in microscopic analysis of evidence before it in terms of the common-law cautions. Thus subject to this requirement, the court will be able to clear up the doubts raised by the hearsay evidence through questioning the original adducer of the evidence while interlinking the adduced evidenced with what the accused has to put to the witness as a defence. This helpful exercise is absent in the case where the accused is deemed to have consented to the admission of the hearsay evidence in terms of section 3(1)(a). Unlike in section 3(1)(b) there would be no possibility to determine credibility of the maker of the statement as no one would be called to confirm the hearsay evidence. 


\section{The application of section 3(1)(b) Compared to section 3(1)(a)}

Where evidence is tendered in terms of subsection 3(1)(b), unlike in the case where parties have consented to the admission of hearsay evidence in terms of section(3)(1)(a), the witness upon whose credibility the probative value of the lead evidence depends would later come to confirm the hearsay evidence. Upon the witness's appearance in court, an investigation on credibility issues pertaining to the provisionally admitted hearsay evidence would take place. Section $3(1)$ (b) recognizes the indispensable nature of the common-law cautions in the proper administration of justice because the determination as to whether to admit hearsay evidence under this section involves the satisfaction of common-law cautionary factors.

These include the need for witnesses to testify under the sanction of an oath or a solemn affirmation and have them undergo cross-examination by the party against whom the witness is called. This assists the court to determine the witness's powers of perception; whether the witness had opportunity to observe and test the extent of his/her attentiveness in observing. In addition the court would be able to find out if the witness has enough strength of recollection, and test the witness's disposition to speak the truth. It is then that the court would be able to satisfy itself whether the witness could be trusted as well as the truth of what the evidence entailed would be tested. These processes will also help in unravelling whatever possible doubts against the hearsay evidence, compared to other evidence available before court. The court would then determine the probative value of the hearsay evidence previously brought before court and thus eliminating any potential prejudices if such evidence could be admitted (per Holmes $\mathrm{J}$ in $S \vee$ Libazi supra par 14; as well see Litako v $S$ supra par 48).

Amidst these processes, section 3(1)(b) invokes the court to pay regard to the common-law cautionary rules of evidence. These require courts to exercise caution regarding the nature of the evidence tendered before it. In attempting to reduce the risk of an incorrect finding based on the suspect evidence, courts have to stay suspect of evidence which practice has proved suspicious (S v Hlapezula 1965 (4) SA 439 (A) 440D-H).

To name but a few, practice has amongst others established evidence from single witnesses (see Schwikkard and Van der Merwe Principles of Evidence 546-557), confessed criminals and criminal associates ( $S$ v Masuku 1969 (2) SA 375(N); refer as well to $S v$ Khumalo 1998 (1) SACR $672(\mathrm{~N})$; and S $v$ Mashumpa 2008 (1) SACR 126 (E)) to be suspect and deserving of a cautious approach by courts if they have to depend on it to decide cases. (Suspect evidence worthy of caution includes as well all evidence whose admissibility is subject to cautionary rules. See Schwikkard and Van der Merwe Principles of Evidence 546-557.)

\section{Caution on single witnesses}

In $R$ v Mokoena (1932 OPD 79 80; and as well see $S v$ Webber 1971 (3) SA $754(\mathrm{~A})$ ) the court cautioned against deciding a matter on uncorroborated evidence of a single competent and credible witness (s 208 of Criminal 
Procedure Act allows for conviction based on single-witness evidence). For the purpose of the cautionary rule, a single witness is a witness who, without corroboration from any of the other witnesses called by the State, gives evidence which incriminates the accused. Even two witnesses who recite identical versions of the facts in issue ought to be treated as single witnesses. $R v$ Mokoena (supra 80) held that courts have to rely only on this evidence if it is clear and satisfactory in every material aspect. Thus State cannot invoke this section when a witness has an interest or bias adverse to the accused, where he has made a previous inconsistent statement, where he contradicts himself and so on. Where such factors are present, the evidence insinuates bias and therefore the court must assess its intensity in the light of the totality of the evidence. The court will also be doubtful of such evidence and may draw an adverse inference if the State does not call a witness on the list of witnesses supplied to the accused, and who are in a position to corroborate the evidence of the State's single witness.

\section{Caution on confessions}

Section 209 of Criminal Procedure Act allows for the conviction of an accused person on a single evidence of confession by an accused (for their definition and requirements for admissibility, see $S v$ Yende 1987 (3) SA 367 (A); $R v$ Becker 1929 AD 167; and S v Mpetha (2) 1982 (2) SA 406 (C)) that the accused committed the offence in question, if such confession is confirmed in all material aspects and even where the confession is not so confirmed, if the offence is proved by evidence other than the confession, to have been actually committed. Confirmation in material aspect means evidence outside the confession which corroborates it in some material aspect, for example confession, that an accused has shot the deceased with a $9 \mathrm{~mm}$ pistol would be confirmed by evidence that there was a bullet in the deceased body matching the gun, and a confession to theft of a complainant's property would be confirmed by evidence that the property is missing.

Although as a general rule there is no limitation on the kind of evidence which may adequately confirm a confession or prove aliunde the commission of the offence charged, an extra curial admission by the accused, which ordinarily constitutes sufficient proof of the facts admitted, is not evidence for the purpose of the evidence aliunde in terms of section 209 of the Criminal Procedure Act. Moreover, in most circumstances, to hold that an extra-curial confession could be confirmed by an admission would be to defeat the object of the legislature, which is to preclude the conviction of an accused person of an offence he has not actually committed.

However, an extra-curial admission could be sufficient if it was made in circumstances which indicate that it is highly likely to be true, even if made by necessary implication ( $S$ v Maleka 2005 (2) SACR 284 (SCA)). An intra-curial admission made by an accused in his statement under section 115 of the Criminal Procedure Act, or in his answer to questions to him under section 115 of the Criminal Procedure Act, could alone furnish the confirmation required by section 209 of the Criminal Procedure Act. If the confession is to be regarded as conclusive on the ground that the offence is proved to have been committed through evidence other than the confession, which is by 
evidence aliunde, then every element of the offence must be established by that evidence.

For example, the offence of murder is not proved by the mere finding of the deceased's body with bullet wounds in the head. There is no limit on the kind of evidence which may prove the commission of the offence. Circumstantial evidence is permissible, and so is documentary evidence. A plea of guilty is, however, not evidence. Neither is a formal admission made in terms of section 220 of the Criminal Procedure Act. These may thus not be relied upon as evidence of the commission of the offence.

\section{Caution on criminal associates}

It is possible for courts to convict an accomplice on the evidence of an accomplice. However, courts are cautious that such evidence pass particular tests to avoid prejudice of the other. A court will normally only convict on the evidence of an accomplice if there is present some factor reducing the risk of a wrong conviction. $S \vee$ Hlapezula (supra $440 \mathrm{D}-\mathrm{H}$ ) held that the rationale for the cautionary rule relating to accomplices and the nature of the rule hinge on the need to reduce the risk of a wrong conviction on the basis of evidence by accomplice. The cumulative effect of the following factors cannot be overemphasized: the first factor is that the accomplice is a self-confessed criminal; second, that he may for various reasons in his own interest falsely implicate the accused; third, that by reason of his inside knowledge he has a deceptive facility for convincing description. For the purposes of the cautionary rule relating to accomplices, an accomplice is a co-perpetrator; factual accessory; anyone else who has committed an offence in relation to the same criminal transaction which forms the subject matter of the charge, may also be an informer, where he/she has a possible false motive for implicating the accused or where he/she is because of his/her participation in the crime in a position to deceive by convincing description. Similar cautions are still regarded of essence even where courts deal with hearsay evidence of the nature where co accused's disavowed statements are sought to be introduced to found conviction for a co-accused ( $S \vee$ Libazi supra par 14; Balkwell $v$ S supra par $32-35 ; S \vee$ Ramavhale supra $649 \mathrm{c}-\mathrm{d}$; and $S v$ Mamushe supra par 16).

This is why courts have to take heed of the established cautionary rules as tools to the recognition of potential dangers to abortive justice. Courts have to exercise safeguards with the aim to reducing the risks of wrong convictions. Courts can safely convict where such evidence is corroborated, and they have to observe the need for the tendered evidence to prove the guilt of an accused beyond a reasonable doubt. Apart from corroboration, courts have to observe factors indicating trustworthiness of the accomplice's evidence such as the failure of the accused to take a stand and deny the accomplice's evidence on oath. Further, if the accused chose to testify, and has given evidence which has been independently shown to be false, as well as the fact that the accomplice has implicated someone near and dear to him.

The implied requirement for caution in section 3(1)(b) enables courts to ward off possible prejudices against the accused. These would obviously not be exercised with respect to section 3(1)(a). 
Lack of application of cautionary rules and lack of courts' interests to delve into the tests establishing the best interests of justice before they can admit hearsay evidence, means that an accused whose legal representative consents to the admission of hearsay evidence, is bound to face the least evidence by single witnesses, confessed criminals and criminal associates which would go through untested. This creates the worst scenario considering the rationale behind the enactment of the Act, something that would not have been perceived by the legislature. I submit that this prejudicial circumstance for an accused is tantamount to what the Constitutional Court held against in $S$ v Molimi (supra par 42; and also consider $S$ v Ramavhale supra 649c-d), namely that an accused should not be given the task of making a case against himself by letting him/her defend evidence marred with uncertainties. Doing so, the Court held, is contrary to the meaning of the adversarial litigation system embraced by the South African criminal-justice system.

\section{The application of section $3(1)(c)$ compared to section 3(1)(a)}

Unlike in the case of section 3(1)(a) which demands no caution from courts as parties would have consented, section $3(1)$ (c) constitutes a duty ( $S$ v Molimi supra; and $S \vee$ Ndhlovu (SCA) supra) in law for courts to make certain considerations against the admissibility of hearsay evidence, where evidence would not be confirmed by the actual giver of direct evidence. The situation in section $3(1)(c)$ is more challenging than the situation in section $3(1)(b)$, because where this section applies, the accused would ultimately be able to cross-examine the person upon whose credibility the hearsay evidence depends. This means that in terms of section $3(1)(b)$, the exercise of caution is easier than in the case of section 3(1)(c). To satisfy section 3(1)(c) provision, courts inform their discretion as to whether to admit hearsay evidence or not.

This section explicitly binds courts to inquire whether such evidence would satisfy the interests of justice before it could be admitted. (In particular on the highlight of what the interests of justice mean in the context of the Act see the holding in S v Molimi supra par 35-37; and S v Ndhlovu (SCA) supra par 17 and 18.) If the answer to the enquiry is in the affirmative, the courts would undoubtedly admit the hearsay evidence ( $S$ v Molimi supra par 35-37; and $S$ $v$ Ndhlovu (SCA) supra par 17 and 18). In its investigation, aimed at warding off the injustices of blindly admitting hearsay evidence where crossexamination is absent, the court is guided by the following seven declared essentials which have to be applied cumulatively in respect of the hearsay evidence presented before them. (Eg, these injustices include instances where courts may be presented with evidence originating from persons whose credibility is doubtful, such as potential accomplices; single state witnesses; people of infirm mind; confessed criminals and criminal associates.)

The first duty relates to the need to observe the nature of the proceedings (s 3(1)(c)(i) of Act 45 of 1988) in which the particular hearsay evidence is being tendered; the second duty is that courts would determine the reason why the person upon whose credibility and the probative value the evidence depends cannot come to testify before court (s 3(1)(c)(ii) of Act 45 of 1988); on the third requirements the court would determine the extent of prejudice ( $\mathrm{s}$ 
3(1)(c)(iii) of Act 45 of 1988) the evidence poses. It would be determined in this instance if the court would not be delving into allowing the throttling of procedure unjustly so as in the situation where section 3(1)(a) is invoked, and the accused finds himself in a situation where he has to clarify the State's doubtful evidence.

Fourthly, the court would determine the probative value (s 3(1)(c)(vi) of Act 45 of 1988) of the tendered hearsay. This means that the court would get into an exercise where it determines if the hearsay evidence has the potential to help in proving certain issues in order to establish their relevance to the matter before the court on the other hand, will find out whether the evidence being tendered will add weight in favour of either of the parties to the litigation. On the fifth note, the nature of evidence (s 3(1)(c)(v) of Act 45 of 1988) will be looked into whilst determining the purpose for which the evidence is tendered as the sixth factor (s 3(1)(c)(vi) of Act 45 of 1988). The seventh and final leg of enquiry, demands courts to take into account common-law factors if the courts are of the opinion that such factors ought to be considered (s 3(1)(c)(vii) of Act 45 of 1988).

It can therefore be inferred that all in all the rationale of section $3(1)(c)$ is to attempt to mitigate potential unconstitutional prejudices against the accused where hearsay evidence is invoked. It is therefore trite to say that the purpose of section 3(1)(c) principles is to inform an exercise of a court's duty in refining and turning to admissible evidence what would otherwise be inadmissible hearsay evidence. This is why the misapplication of these principles led to the flaw of justice causing several trial courts' decisions to be turned down on appeal. Accused persons would appeal that either their substantive or procedural rights were negatively affected.

At the centre to the challenges to procedural prejudice is the Constitutional Court decision in S v Molimi (supra). In this case the appellant challenged the admission and reliance on hearsay evidence emanating from the coaccused's statements made upon arrest. The trial court in this matter had relied on the $S v$ Ndhlovu (supra) decision of the Supreme Court of Appeal which was later subjected to extensive scrutiny by the Constitutional Court. At the trial, the High Court had contrary to the demands of section 3(1)(c), made hearsay evidence play a decisive role, even though the SCA judgment it had relied on had considered that a matter cannot be decided on the basis of hearsay evidence, as such would not pass the rationale of Act 45 of 1988 ( $S \mathrm{~V}$ Ndhlovu supra).

In endeavouring to make a finding on the question as to "whether an accused's out-of-court statements incriminated a co-accused, if disavowed at the trial, can nevertheless be used in evidence against the latter" ( $S v$ Ndhlovu supra), the appeal judge had confirmed the decisive factor played by the hearsay evidence in convicting the appellant in the court a quo ( $S$ v Ndhlovu 2001 (1) SACR 85 (W) (per Goldstein J)). He had made an exception that where a co-accused's confession implicates that another such evidence can be used against a co-accused. He had in the midst of his judgment referred to the decision in $S \vee$ Ramavhale (supra 649c-e), which rightly interpreted the application of section $3(1)$ (c) to imply the court's careful consideration of hearsay evidence and ability to place it on the appropriate pedestal ( $S v$ Ramavhale supra $651 \mathrm{~b}-\mathrm{g})$. 
In $S$ v Ramavhale (supra 649c-e) the use of hearsay evidence against an accused was held to be contrary to "both experience and elementary fairness" but to ought to happen in "extraordinary circumstances" ( $S \vee$ Ramavhale supra $649 \mathrm{c}-\mathrm{e})$. That meant that only under compelling circumstances would the court rely on hearsay evidence and that in no circumstances would hearsay evidence play a pivotal role in convicting an accused.

Regardless of statutory relaxation of the rigid principle in common law, the courts are still supposed to apply caution when admitting hearsay evidence because of its possible unreliability ( $S \vee$ Ramavhale supra $651 \mathrm{~b}-\mathrm{g}$ ). The court disapproved of the common practice of provisional admission of hearsay evidence and emphasized the duty that courts have to guard against procedural tormentations against the accused, such as where the accused is made to make a case against himself via the introduction of hearsay evidence at the stage where the accused had already testified (see $S \vee$ Molimi supra par 39 and 40).

This I would submit, is contrary to the clear right against self-incrimination.

Still in pursuit of section 3(1)(c) justice, after $S \vee N d h l o v u$ (supra), the Supreme Court of Appeal in the recent case of Litako v $S$ (supra) heard a matter involving five appellants whose grounds of appeal were that the High Court had erroneously convicted them on the evidence entirely based on a co-accused disavowed statement. The co-accused in the court a quo had appealed as first appellant. In the trial within trial held at the court a quo, he had denied the statement he made to the police upon arrest, mentioning that he was induced through torture to give the statement. (This allegation shows that the State had acted contrary to the requirements of $s 217(1)$ of the CPA and thus the confession ought to be perceived unconstitutional because it was obtained contrary to the principle of fairness in s 35 of the Constitution.)

The contents of the statement incriminated his co-accused and exculpated him. Regardless of that, the trial court held the statement admissible against all the appellants, including a co-accused who did not appeal. The High Court Judge, in Litako $v S$ (supra) had, for purposes of convicting the appellants, erroneously found the statement by the first appellant to be corroborating some evidence which was held defective by the appellate court (par 8-22 and in particular par 23 of the judgment).

Regardless of the first appellant's failure to testify before the court during the trial and thus leaving the court with unconfirmed evidence amounting to hearsay, the court still relied on the evidence. The court found the evidence admissible in terms of section 3 of the Law of Evidence Amendment Act 45 of 1988. Further, the court appreciated no prejudice against all the accused, mindful of the fact that the rest of the accused testified and "underwent the cross-examination unscathed" (Litako v S supra par 27).

Like in Ndhlovu, the High Court in Litako v $S$ (supra), did not consider the provision of section 3(1)(c) and no analysis of cumulative factors mentioned above were ever subject to scrutiny. The trial judge had referred to the cases of $S v$ Molimi (supra) and $S v$ Ndhlovu (supra), respectively, as the authorities for admitting first appellant's statement as evidence against his co-accused in terms of section 3(1)(c). The Trial Court erroneously interpreted $S v$ Molimi (supra) to have decided against the admission of a confession by one of the 
co-accused against the others, where the other accused did not know in advance the existence of such evidence against them. In the present case, the trial judge reckoned the co-accused were supplied with the statement all along (see the arguments in Shabalala v Attorney-General of Transvaal 1995 (12) BCLR 1593 (CC)).

The Court was thus referring to the stage prior to the trial where the accused received the police docket containing, amongst others, witness statements. On that basis the court concluded, the appellants could not invoke $S \vee$ Molimi (supra). I submit that this holding was wrong because it cannot be said that a mere existence of a potential witness statement in the police docket means that the statement is evidence per se. The statement would become evidence upon being declared admissible by the court, and it is then at that moment that statements could become the issues of the trial. Section $3(1)$ (c) therefore informs the court on how to utilize its determination of the necessity and reliability of the statements handed up to the court by the parties for purposes of proving their case.

In $S v$ Ndhlovu (supra), the matter which was decided prior to $S v$ Molimi (supra), the Supreme Court of Appeal upheld the decision of the High Court, where it had held that evidence based on the co-accused's disavowed statements were admissible against others. In this case four accused were charged with murder and armed robbery. Eye-witness evidence tendered was found wanting and the court held it of no value (see Litako $v S$ supra par 27). The court then turned to statements made by accused 3 and 4 . Accused 3 had mentioned to the police that he was not alone when he and others shot the deceased. He had mentioned that there were four of them. He further exculpated himself and said he was not the one who pulled the trigger, but that is was accused 1 that was the guilty one.

He had also explained to the police how they went about shooting the deceased and robbed him of the cell-phone. Accused 4, on the other hand, had made a written statement implicating him and the rest of the accused. In admitting these statements, the court considered that the fact that the coaccused had disavowed the statements does not change the nature of the enquiry as to whether the administration of justice requires their admission. The court further related the measure of the probative value of the statements to the credibility of the co-accused at the time they were making the statements, that is when they were arrested. In a nutshell, the court reasoned that the two statements were able to persuade reasonable men of the truth of the statement that it was the rest of the accused who killed the deceased and robbed him of the cell-phone, and that those statements were sufficient without the evidence of the eye witness.

I submit that this reasoning, although seeking to establish the interest of justice in terms of section 3(1)(c), does not fit in with the rationale of the same principle. In $S$ v Molimi (supra par 35) the Constitutional Court citing $S v$ Shaik (2007 (1) SA 240 (SCA) par 170), made it mandatory that courts "have regard to every factor (author's own emphasis) that should be taken into account, more specifically, to have regard to the factors mentioned in section 3(1)(c). Only if, having regard to all these factors cumulatively, it would be in the interests of justice to admit the hearsay evidence, should it be admitted" ( $S \mathrm{~V}$ Shaik supra par 170). 
It is my submission that the courts as custodians of the law must make thorough considerations of all existent factors in law, be it common law or statutory, meant at safeguarding prejudices against fair trial principles established in section 35 of the Constitution before they resort to admitting hearsay evidence. This therefore means that the determination of whether it is in the interest of justice to admit hearsay evidence is a consideration that thoroughly deals with the requirement of section 3(1)(c) and further than that, a consideration of other factors in our law.

It would therefore be trite to conclude that admissible hearsay evidence would satisfy the best interest of justice when prejudice to the party whom the evidence is against, rates low and even though fact-finding processes were disregarded, the probative value of such tendered evidence would rate high. This is possible when the hearsay evidence does not play the major role, but a pivotal role as a mere thread leading to the available evidence. This was not the scenario in the $S \vee$ Ndhlovu (supra), matter. Instead the available evidence was to major extent hearsay. In Litako $v S$ (supra), the recent Supreme Court of Appeal decision, the Court directly slammed at $S$ v Ndhlovu (supra), when it observed that, $S v$ Ndhlovu (supra), "in dealing with the constituent parts of section $3, \ldots$ offers no guidance as to how the receipt of the extra-curial admissions which it allows under that section, should be approached, given the rationale at common law for their exclusion, or what role, if any, the various common-law safeguards should play ..." (Litako $v S$ supra par 46; and see as well Balkwell $v$ S supra par 32-35 which raises concerns on the negative effects of $S v$ Ndhlovu in our law.) The Court held the effect of $S v$ Ndhlovu (supra), in our hearsay jurisprudence, to be similar to a pen (striking) through all those well recognized common-law safeguards and (summarily jettisoning them; and Litako $v S$ supra par 46).

This concern by the Supreme Court of Appeal comes after the principle in $S$ $v$ Ndhlovu (supra) became a norm among trial courts for a while. In $S v$ Saeed (supra par 41), hearsay evidence played a pivotal role to the finding and conviction of the accused for murder, amongst other charges. The State witness, Mr Rehman Khan, gave various statements to the arresting officers, namely Warrant Officer Eben van Zyl, Warrant Officer Linda Steyn and Captain FJ Laux. The State called all three to come and narrate Rehman Khan's statements as hearsay evidence.

They individually testified about encounters they had had with him. Their evidence was backed up by means of statements that they alleged were written by the original declarant, Mr Rehman Khan, who never testified. These statements were basically exculpatory. In some of these statements Khan had sought to exculpate himself while in others he had placed a version that he had no role to play in the murder although he witnessed the murder.

Apart from these statements the State introduced evidence by one of the officers to whom the witness had shown where the murder victims were buried. The wives of some of the victims had also tendered hearsay evidence that they spoke to their husbands before their deaths, and had indicated that they were at the accused's residence.

A telephone track record also reflected that the wives had at some stage communicated with recipients who were in that vicinity. These did not reflect the contents of communication. Although the Court held that the value of the 
hearsay evidence based on the telephone communications the two wives had had while trying to establish the whereabouts of their husbands with some persons, who were never called to testify, was not of much value in proving ( $S$ $\checkmark$ Saeed supra par 41 ) the accused's guilt, the Court found the accused guilty amongst others of murder on the gravity of the hearsay evidence from the missing declarant's statements as narrated by the arresting officers. (The Court held in this manner regardless of its considerations regarding the potential prejudices that hearsay evidence by Rehman Khan-the accomplice has against the accused.) In regard to the nature of the evidence and its origin, the Court ought to have warned itself of the danger it posed, and the fact that it played a pivotal role in the conviction of the accused, and in the absence of direct evidence not convicting the accused of murder. An appeal was not lodged against this matter. In the light of the current decision of the SCA, Litako v S supra, such an appeal has a potential of being upheld.

The current struggle in regard to determining admissibility of hearsay evidence, even in terms of section 3(1)(c) reveals that lack of a consistent understanding of the demands of the Act in victimizing accused. Thus, except with regard to the application of section 3(1)(b), where courts, even though they can admit hearsay evidence, would still determine the credibility of the concerned witness and thus caution themselves accordingly, that the admissibility of hearsay evidence is potentially prejudicial. This means that it cannot be overlooked that section 3(1)(c) does cause a flaw in the criminaljustice system by not allowing an attempt by courts to satisfy the interests of justice. Thus a lack of protective measures against accused persons standing at the mercy of courts before hearsay evidence is deemed admissible, acts contrary to the rationale of the Act itself, let alone the Constitutional demands that this Act ought to satisfy.

\section{Conclusion}

The law is clear that the admissibility of hearsay evidence does not supersede the admissibility of direct evidence. In addition, admission of hearsay evidence cannot be contrary to the observance of the supreme law of the land namely, the Constitution and further contrary also to the provisions of other statutes. It would be in order therefore to conclude that the application of section 3(1)(a) ought not to pose the mentioned problems. Most definitely, these difficulties associated with section 3(1)(a) call for an urgent solution.

I propose a dual solution which would ultimately entail the need to exclude the application of section 3(1)(a). The law must not allow parties to directly declare their consent to waive an opportunity for courts to determine the potential prejudices. On that note there is a need to propose a reinterpretation of the statute to mean that the test inferred in section 3(1)(c), namely the need to establish the interest of justice in admitting hearsay evidence, also applies to section 3(1)(a), where parties consent to hearsay. I would earnestly propose a move similar to the one adopted by Canada (this approach has been adopted in Ares $v$ Venner [1970] SCR 608 618; and in $R v$ Khan [1990] 2 SCR 531). Referring to this approach, in Myers $v$ Director of Public Prosecutions ([1965] AC 1001 1040-1041), the dissenting judgment of Lord Pearce, held the following, to be appropriate safeguards for declaring hearsay evidence admissible, namely, 
(i) the case must be one in which it is difficult to obtain other evidence;

(ii) the declarant must be disinterested - disinterested in the sense that the declaration was not made in favour of his interest;

(iii) the declaration must be made before the litigation or dispute so that it was made without bias.

The rationale of Lord Pearce's safeguards is the need to focus on "necessity and reliability" (Myers $v$ Director of Public Prosecutions supra 1040-1041) when dealing with admissibility of hearsay. Courts are bound to retain discretion, "to exclude evidence that meets the criteria of reliability and necessity if its admission would result ..." (Myers $v$ Director of Public Prosecutions supra 1040-1041) in the violation of the elements of constitutional right to fair trial. The South African system should not rely on either rigid or flexible application of the rule against the admission of hearsay evidence. Instead courts must be vested with power to develop the common law and therefore create new exceptions to the admissibility of hearsay evidence where need arises. This approach will not pose difficulties because of the doctrine of the supremacy of the Constitution. Our Constitution is capable of safeguarding the interests of justice depending on the circumstances of individual cases.

'Mampolokeng Mary-Elizabeth Monyakane University of South Africa (UNISA) Advocate of the High Court of South Africa 